\title{
KARANTINA DAN HOSPITALITAS YANG BERISIKO SEBAGAI RESPONS GEREJA DI SEPANJANG SEJARAH PANDEMI
}

\author{
QUARANTINE AND HOSPITALITY AT RISK AS THE \\ CHURCH'S RESPONSE THROUGHOUT PANDEMIC \\ HISTORY
}

\author{
Yohanes Krismantyo Susanta, Daniel Fajar Panuntun \\ Institut Agama Kristen Negeri Toraja, Indonesia \\ yohanessusanta@gmail.com
}

DOI: $10.31291 /$ jlk.v19i1.842

Diterima: 03 Mei 2020; Direvisi: 20 Juni 2021; Diterbitkan: 30 Juni 2021

\begin{abstract}
This paper discusses the hospitality of early Christians in the face of pandemics that have occurred throughout church history. A pandemic that lasts a long time and results in many deaths will cause mass hysteria. This was experienced by the global population at the end of 2019, namely the Covid-19 pandemic. Humanity is trying to overcome the spread of disease medically but also needs to be able to provide the right formulation of social attitudes in dealing with pandemics. The purpose of this paper is to find out the response of early Christians in the face of pandemics in the past and to draw theological reflections and lessons from church fathers regarding the Covid-19 pandemic. This paper uses a historical approach. Data collection was carried out through a study of literary criticism regarding the study of the history of the Church's history and the response of the Church Fathers in facing the pandemic in their respective times. This study finds that the history and responses of the church fathers emphasized the importance of quarantine and hospitality in dealing with the pandemics that occurred in their time. The implementation of this attitude is to emphasize the importance of quarantine and friendliness in dealing with the pandemic, including the current Covid-19 pandemic.
\end{abstract}

Keywords: Church Fathers, Covid-19, Hospitality, Pandemic, Christian 


\begin{abstract}
ABSTRAK
Tulisan ini membahas tentang hospitalitas orang Kristen awal dalam menghadapi pandemi yang berlangsung di sepanjang sejarah gereja. Pandemi yang berlangsung lama dan mengakibatkan kematian dalam jumlah besar akan menimbulkan suatu histeria massal. Hal ini yang dialami oleh penduduk global pada akhir tahun 2019, yaitu pandemi Covid-19. Umat manusia berusaha mengatasi penyebaran penyakit tersebut secara medis, akan tetapi juga perlu mampu memberikan suatu rumusan sikap sosial yang tepat dalam mengatasi pandemi tersebut. Tujuan tulisan ini untuk mengetahui respons orang Kristen awal dalam menghadapi pandemi di masa lalu serta menarik refleksi teologis dan pelajaran dari Bapa-Bapa gereja terkait dengan pandemi Covid-19. Tulisan ini menggunakan pendekatan kualitatif dengan pendekatan sejarah. Pengumpulan data dilakukan melalui studi kritik literatur mengenai kajian sejarah Gereja dan respons Bapa-Bapa Gereja dalam menghadapi pandemi pada zamannya masing-masing. Kajian ini menemukan bahwa sejarah dan respons BapaBapa gereja menekankan pentingnya sikap karantina dan hospitalitas dalam menghadapi pandemi yang berlangsung pada zamannya. Implementasi sikap ini untuk menekankan pentingnya karantina dan hospitalitas dalam menghadapi pandemi termasuk pandemi Covid-19 pada saat ini.
\end{abstract}

Kata kunci: Bapa Gereja, Covid-19, Hospitalitas, Pandemi, Sejarah Kekristenan

\title{
PENDAHULUAN
}

Penyakit yang kemudian berkembang menjadi wabah mematikan merupakan kondisi yang ditakuti oleh manusia sepanjang sejarah. Hal ini terjadi karena sebagai makhluk yang bernyawa, manusia memiliki naluri untuk bertahan hidup. Pelbagai wabah yang merenggut kehidupan telah dilewati oleh manusia berdasarkan fakta sejarah yang ada. Pelbagai penyakit seperti kusta, cacar, pes, dan lainnya merupakan jenis-jenis wabah yang pada masanya berhasil menciptakan paranoid karena sifatnya yang mematikan dan belum diketahui teknik penyembuhannya pada saat itu. Hal yang sama dengan itu terjadi pada akhir tahun 2019, yaitu seluruh dunia mengalami pandemi secara global 
yang kemudian dikenal dengan wabah Corona Virus Desease 2019 atau Covid-19. ${ }^{1}$

Pandemi ini merebak pada akhir Desember 2019 di daerah Wuhan, Cina dan menyebar dengan cepat ke pelbagai negara di dunia. Bahkan sejumlah negara telah memberlakukan kebijakan lock down seperti Italia dan sejumlah negara bagian Amerika Serikat. $^{2}$ Gejala penyakit meliputi demam, rasa lelah, sakit kepala, diare, dan pneumonia akut. Penyakit ini sangat menular sehingga diperlukan tindakan pencegahan seperti menghindari kontak secara publik dan melakukan karantina. ${ }^{3}$ Pencegahan berupa pembatasan kontak sosial, isolasi mandiri maupun karantina wilayah dilakukan untuk mengurangi jumlah penyebaran virus tersebut.

Saat ini, manusia di pelbagai belahan dunia sedang mengalami kepanikan karena pandemi tersebut dan mulai melakukan sejumlah cara seperti menimbun pembersih tangan, masker muka, kertas toilet dan air mineral sambil melakukan karantina mandiri. Fokus dari upaya ini, tentu saja sebagai perlindungan diri dan orang lain dari penyebaran virus. Akan tetapi, pada sisi lain, tindakan tersebut dianggap berlebihan dan hanya mementingkan diri sendiri. Manusia seolah kehilangan empati dan hospitalitas kepada sesama tatkala berfokus pada dirinya sendiri. Hospitalitas sendiri merupakan suatu bentuk keramah tamahan seorang tuan rumah dalam memberikan tumpangan bagi tamunya. Hospitalitas merupakan bentuk wujud kasih terhadap

${ }^{1}$ Vina Fadhrotul Mukaromah, "Apa Itu Virus Corona, Yang Jadi Penyebab Penyakit Covid-19, MERS, Dan SARS?," Kompas, diakses 18 Juni 2021, https://www.kompas.com/tren/read/2020/03/17/153000465/apa-ituvirus-corona-yang-jadi-penyebab-penyakit-covid-19-mers-dan-sars?page=all .

${ }^{2}$ Angela Giuffrida and Sam Jones, "Italy to Unveil Lockdown Relief Package as Protests Continue," the guardian, diakses 30 April 2020, https://www.theguardian.com/world/2020/oct/27/italy-to-unveil-lockdownrelief-package-as-protests-continue.

${ }^{3}$ Sasmita Poudel Adhikari et al., "Epidemiology, Causes, Clinical Manifestation and Diagnosis, Prevention and Control of Coronavirus Disease (COVID-19) during the Early Outbreak Period: A Scoping Review," Infectious Diseases of Poverty 9, no. 1 (2020): 1. 
sesama secara nyata dalam kehidupan sehari-hari. ${ }^{4}$ Hal ini tentunya akan memberikan suatu polemik tersendiri sehingga dalam menanggapi kasus pandemi ini diperlukan rumusan yang tepat dalam hal karantina dan bentuk-bentuk hospitalitas dalam menghadapi pandemi Covid-19.

Sejumlah penelitian tentang pandemi Covid-19 telah banyak dihasilkan dari pelbagai disiplin ilmu. Secara khusus dalam bidang kajian ilmu teologi, sejauh pengamatan terbatas penulis, sejumlah penelitian telah dilakukan misalnya yang membahas tentang etika Kristen terkait fenomena pandemi yang justru dijadikan joke atau humor. Sikap tersebut tentu saja cenderung tidak menaruh empati kepada keluarga korban dan juga tenaga kesehatan yang setiap hari berhadapan dengan resiko terpapar Covid-19.5

Kajian teologi dari perspektif pastoral juga telah dilakukan yang membahas bagaimana para lansia menjadi salah satu golongan usia yang tidak hanya rentan terpapar virus tersebut, tetapi juga menjadi pihak yang dipenuhi rasa cemas. Dalam konteks inilah gereja hadir untuk memberikan pelayanan pastoral dan konseling kepada para lansia dalam menghadapi wabah tersebut. ${ }^{6}$ Sementara itu, kajian yang membahas tentang ibadah Kristen di masa pandemi Covid-19 juga telah dilakukan. Dalam kajian tersebut disebutkan bagaimana pihak gereja seharusnya bukan sekadar mengikuti aturan pemerintah lewat pembatasan kegiatan ibadah dalam gedung gereja, melainkan umat juga harus dibekali dengan pemahaman teologis bahwa beribadah tidak

${ }^{4}$ Michele Hershberger, Hospitalitas Orang Asing: Teman Atau Ancaman (Jakarta: BPK Gunung Mulia, 2009), 9.

${ }^{5}$ Yohanes Krismantyo Susanta and Daniel Fajar Panuntun, "Tinjauan Etika Kristen Atas Fenomena Disaster Joke Terkait Pandemi Covid-19," HARVESTER: Jurnal Teologi Dan Kepemimpinan Kristen 5, no. 1 (2020): 14-27.

${ }^{6}$ Eliman Eliman and Aris Elisa Tembay, "Pelayanan Pastoral Bagi Kaum Lansia Ditengah Pandemi Covid-19," Scripa: Jurnal Teologi Dan Pelayanan Kontekstual 9, no. 1 (2020): 48-68. 
hanya dibatasi dengan tempat sebab ibadah kepada Tuhan juga seharusnya tercermin dalam perilaku hidup sehari-hari. ${ }^{7}$

Oleh karena itu, kendati akan meneliti topik terkait pandemi Covid-19 dari perspektif teologi Kristen, kajian ini berbeda dengan kajian sebelumnya. kajian bidang ilmu teologi yang telah dilakukan sebelumnya dalam sejumlah artikel jurnal belum menyentuh aspek sejarah dari pandemi serta menarik pelajaran dari dalamnya. Oleh karena itu, fokus tulisan ini tentang penelusuran jejak kekristenan awal (aspek historis), dalam hal ini, bagaimana orang-orang Kristen awal menanggapi wabah pada masa lalu? Apa yang bisa diajarkan gereja awal kepada kita sehubungan dengan pandemi Covid-19?

Kajian tentang pandemi yang berlangsung dalam sejarah gereja akan dibatasi pada tempo atau kurun waktu $165 \mathrm{M}$ (wabah Antonine) sampai 1578 M (wabah pes di Italia). Sementara itu, pandangan dan pengalaman bapa-bapa gereja akan dibatasi hanya pada enam orang tokoh yang memang berhadapan langsung dengan pandemi pada zamannya, yaitu Cyprianus, Dionysius, Martin Luther, Ulrich Zwingli, John Calvin, dan Carlo Borromeo.

Jenis kajian yang diusung dalam tulisan ini ialah penelitian kualitatif dengan pendekatan sejarah. Pendekatan ini mengutamakan kebenaran makna dibalik data-data yang telah dikumpulkan. $^{8}$ Kajian ini merupakan suatu upaya untuk melakukan kontruksi atas peristiwa-peristiwa yang telah terjadi pada masa lalu (historis), ${ }^{9}$ lalu mendialogkannya secara teologis dengan konsep teologi konstruktif mengenai hospitalitas sebagai tema teologis.

${ }^{7}$ Susanto Dwiraharjo, "Konstruksi Teologis Gereja Digital: Sebuah Refleksi Biblis Ibadah Online Di Masa Pandemi Covid-19," EPIGRAPHE: Jurnal Teologi Dan Pelayanan Kristiani 4, no. 1 (2020): 1-17.

${ }^{8}$ Stevri Indra Danik Astuti Lumintang Lumintang, Theologia Penelitian Dan Penelitian Theologis Science-Ascience Serta Metodologinya (Jakarta: Geneva Insani Indonesia, 2016), 16.

${ }^{9}$ Wagiran, Metodologi Penelitian Pendidikan : Teori Dan Implementasi (Yogyakarta: deepublish, 2019), 131. 
Pengumpulan data dilakukan dengan menggunakan studi literatur. Pengumpulan data dilakukan melalui empat tahap. Pertama, mengumpulkan data-data terkait sejarah pandemi yang dihadapi oleh orang Kristen. Kedua, data-data terkait sejarah respons Bapa-Bapa Gereja dalam menghadapi pandemi. Ketiga, mengumpulkan data terkait teori karantina dan hospitalitas. $\mathrm{Ke}$ empat, melakukan pengumpulan data secara interaktif ${ }^{10}$ untuk menemukan model karantina dan hospitalitas di masa lampau dan keterkaitannya dengan usaha merawat kehidupan di tengah pandemi Covid-19. Tujuan tulisan ini ialah untuk memberikan gambaran dan menganalisis respons orang Kristen dalam menghadapi pandemi di masa lalu yang mengedepankan hospitalitas serta menarik refleksi teologis dan pelajaran dari Bapa-Bapa gereja terkait dengan pandemi Covid-19.

\section{HASIL DAN PEMBAHASAN}

\section{Karantina dalam Pandemi yang dihadapi di Sepanjang Sejarah Orang Kristen Awal}

Gereja tidak asing dengan wabah, epidemi, dan histeria massal. Pandemi tersebut merenggut banyak nyawa dan memunculkan histeria pada zamannya. Berdasarkan catatan sejarah, orang-orang Kristen awal juga menghadapi wabah menge-rikan dan berusaha bertahan di tengah pelbagai wabah tersebut. Menurut catatan sejarah, beberapa wabah atau pandemi yang pernah terjadi di antaranya wabah antonine, wabah cyprian, wabah Justinian, wabah black death, dan wabah pes. Wabah tersebut menewaskan banyak orang pada masanya, termasuk orang-orang Kristen. Wabah tersebut memaksa pemerintah memberlakukan karantina dan isolasi di tiap rumah sakit yang ada guna menekan laju penyebaran wabah mematikan tersebut.

\section{Wabah Antonine}

Sejumlah wabah atau pandemi telah dihadapi oleh orangorang Kristen terdahulu. Wabah pertama yang cukup terkenal

${ }^{10}$ Stephen D. Lapan, MaryLynn T. Quartaroli, and Frances J. Riemer, Qualitative Research: An Introduction to Methods and Designs (New York: Jossey-Bass, 2012), 29. 
terjadi pada $165 \mathrm{M}$ di Roma, pada masa pemerintahan Marcus Aurelius dan membunuh antara seperempat dan sepertiga populasi, termasuk Aurelius sendiri. Dikenal sebagai "Wabah Antonine," penyakit tersebut mempengaruhi dunia Romawi selama hampir dua dua dekade. ${ }^{11}$ Dio Cassius mendeskripsikan bagaimana virus cacar tersebut menyebabkan kematian lebih dari 2000 orang per hari di kota Roma pada tahun 189. Angka kematian penduduk Roma termasuk para prajurit melonjak dari 7-10\% dari populasi menjadi 13-15\% dari jumlah populasi pada masa pemerintahan Aurelius. ${ }^{12}$ Laporan lain menyebutkan bahwa sekitar 3,5 sampai 5 juta penduduk Roma tewas, bahkan wabah tersebut tersebar di penjuru Eropa dan menyebabkan 8\% dari total penduduk Eropa meninggal di tahun 190 M. ${ }^{13}$

Orang Kristen pada saat itu dikambinghitamkan seiring merebaknya wabah tersebut. Mereka dianggap tidak menghormati Dewa Romawi dengan menolak penyembahan yang dilakukan sehingga membuat para Dewa marah dan mengirimkan wabah tersebut. ${ }^{14}$ Orang Kristen pada abad awal Kekristenan diperhadapkan dengan pelbagai tantangan terutama dari kalangan kekaisaran yang tidak menyukai keberadaan mereka, serta tantangan dari wabah yang mematikan itu.

\section{Wabah Cyprian}

Pandemi kedua terjadi pada tahun $251 \mathrm{M}$, dan angka kematiannya setara dengan yang pertama. Jika pandemi pertama adalah penyakit cacar, maka pandemi kedua adalah wabah cam-

${ }^{11}$ Cavan W. Concannon, Assembling Early Christianity: Trade, Networks, and the Letters of Dionysius of Corinth (Cambridge: Cambridge University Press, 2017).

${ }^{12}$ Sarah K. Yeomans, "The Antonine Plague and the Spread of Christianity," Biblical Archaeology Review (2017): 22-23.

${ }^{13}$ Concannon, Assembling Early Christianity: Trade, Networks, and the Letters of Dionysius of Corinth, 157.

${ }^{14} \mathrm{~S}$. Sabbatani and S. Fiorino, "The Antonine Plague and the Decline of the Roman Empire," Le infezioni in medicina: rivista periodica di eziologia, epidemiologia, diagnostica, clinica e terapia delle patologie infettive 17, no. 4 (2009): 261-275. 
pak. ${ }^{15}$ Pandemi kedua dikenal dengan nama "wabah Cyprian." Dari Roma, wabah tersebut akhirnya menyebar ke Yunani dan lebih jauh ke timur, ke Siria. Wabah itu berlangsung hampir 20 tahun. Pada puncaknya dilaporkan membunuh sebanyak 5.000 orang per hari di Roma. Mereka yang terinfeksi ditinggalkan oleh keluarga mereka untuk mati di jalanan. Pemerintah tidak berdaya dan Kaisar sendiri menyerah pada wabah tersebut. Para pendeta Pagan meninggalkan kuil-kuil mereka. Orang-orang terlalu lemah untuk membantu diri mereka sendiri. Jika bukan wabah cacar yang menyebabkan kematian, maka kelaparan, kehausan, dan kesepian melanda mereka yang ditinggal sendirian. ${ }^{16}$

Selain ribuan orang meninggal perhari di Roma dan sekitarnya, wabah itu merenggut nyawa dua kaisar: Hostilian pada 251 M dan Claudius II Gothicus pada 270 M. Kondisi kekaisaran yang memburuk sekaligus melemahkan kemampuan Roma untuk menangkis serangan dari pihak luar. Meluasnya penyakit juga menyebabkan populasi di pedesaan mengungsi ke kota-kota. Pengabaian ladang bersama dengan kematian petani yang tersisa menyebabkan jatuhnya produksi pertanian. ${ }^{17}$ Wabah mematikan tersebut turut andil menyebabkan pergolakan politik, militer, ekonomi dan agama. Uskup Cyprianus menulis kejadian itu dengan sangat rinci dalam karyanya De Mortalitate ("On Mortality"). Penderita mengalami serangan diare, muntah terusmenerus, demam, tuli, kebutaan, kelumpuhan kaki, tenggorokan bengkak, dan darah memenuhi mata mereka. Sumber penderitaan yang mengerikan ditafsirkan oleh orang-orang kafir sebagai hukuman dari para dewa. Dunia Mediterania pada masa itu memahami penyakit sebagai hal yang bersifat supernatural. ${ }^{18}$

${ }^{15}$ Rodney Stark, The Triumph of Christianity: How the Jesus Movement Became the World's Largest Religion (United States: Harper Collins, 2011), 74.

${ }^{16}$ Simon Ponsonby, Loving Mercy: How to Serve a Tender-Hearted Saviour (Oxford: Monarch Books, 2012), 155.

${ }^{17}$ Glen Scrivener, "Pandemics and Public Worship Throughout History," accessed April 30, 2020, https:/www.thegospelcoalition.org/article/ 4-lessons-church-history/.

${ }^{18}$ Irwin W. Sherman, The Power of Plagues (Washington: ASM Press, 2017), 65 . 


\section{Wabah Justinian}

Wabah Justinian berkecamuk di Eropa Mediterania pada tahun 542-543 M. Procopius melaporkan bahwa epidemi itu bertahan selama empat bulan di Konstantinopel dan pada puncak epidemi, sepuluh ribu orang meninggal per hari. ${ }^{19}$ Wabah ini memiliki kemiripan dengan wabah black death, yang disebabkan oleh bakteri Yersinia Pestis, yang sekarang dikenal dengan penyakit pes. Penyakit ini berasal dari tikus hitam (Rattus ratus) yang ada di dalam kapal gandum yang berasal dari Afrika Utara. Wabah ini sangat meluas hingga Sang Kaisar Justinus sendiri terkena penyakit ini meskipun tidak sampai mati. Mayat bertebaran sangat banyak di jalan-jalan karena kasus kematian yang sangat tinggi. Hewan pun juga terpapar wabah ini sehingga bangkainya perlu pembuangan yang tepat. ${ }^{20}$ Wabah ini sangat memukul pemerintahan Romawi dengan banyaknya korbah jiwa yang jatuh. Wabah ini pula merupakan wabah terakhir yang menyerang kekaisaran Roma hingga pada akhirnya runtuh. Wabah antonine plague, Cyprian plague, dan Justinian plague merupakan tiga wabah besar yang menyerang kekristenan di bawah naungan pemeritahan kekaisaran Romawi. Meskipun pada akhirnya kekaisaran Romawi runtuh namun kekristenan dapat tetap bertahan. ${ }^{21}$

\section{Wabah Black Death}

Pada bulan Oktober 1347, sebuah kapal dagang Genoa yang baru tiba dari Krimea merapat di sebuah pelabuhan di Sisilia. Di kapal naas tersebut, orang-orang yang mati dan sekarat berbaring di dayung. Para pelaut memiliki pembengkakan hitam seukuran telur di ketiak dan pangkal paha mereka. pembengkakan tersebut yang mengeluarkan darah dan nanah, serta

${ }^{19}$ Joseph P. Byrne, Encyclopedia of the Black Death (California: Library of Congress Cataloging-in-Publication Data, 2012), 198.

${ }^{20}$ Sherman, The Power of Plagues, 65.

${ }^{21}$ Sherman, The Power of Plagues, 65. 
bercak hitam pada kulit. ${ }^{22}$ Orang sakit menderita rasa sakit yang hebat dan meninggal dalam lima hari setelah gejala pertama. Gejala lain muncul pada beberapa korban berikutnya: demam terus menerus dan meludah darah. Para korban ini batuk, banyak berkeringat, dan meninggal dalam waktu tiga hari atau kurang, terkadang dalam 24 jam. Para dokter kewalahan, bahkan beberapa dari mereka meninggal di hadapan pasien. ${ }^{23}$

Wabah ini meluas ke penjuru Eropa dan dikenal sebagai black death atau kematian hitam. Di Avignon, Prancis, jumlah korban jiwa 62.000. Di Siena, Italia, ketika black death mengambil lebih dari setengah penduduk, pekerjaan pembuatan katedral ditinggalkan begitu saja. ${ }^{24}$ Pembangunan katedral yang direncanakan menjadi yang terbesar di dunia pada masa itu. Hakim dan notaris menolak untuk datang dan membuat surat wasiat orang yang sekarat, bahkan para imam tidak datang untuk mendengarkan pengakuan dosa mereka. Orang-orang saling menjauhi, suami atau istri saling meninggalkan, ayah dan ibu meninggalkan anak-anak mereka, seolah-olah mereka adalah orang asing. Di tengah terbatasnya pengetahuan terkait wabah yang terjadi, banyak orang atas inisiatif pemimpin umat Kristen pada saat itu berusaha melakukan pelbagai kegiatan keagaamaan dengan mengumpulkan massa untuk mengatasi wabah tersebut. Suatu tindakan yang memperparah keadaan karena makin banyak orang yang terinfeksi wabah mematikan itu. ${ }^{25}$

Situasi semakin kacau sebab orang-orang mulai mencari kambing hitam yaitu orang Yahudi. Orang-orang Yahudi dituduh meracuni sumur-sumur kota. Hukuman gantung di atas pohon atas orang-orang Yahudi dimulai pada musim semi 1348 setelah wabah kematian pertama. Di Prancis, orang-orang Yahudi diseret dari rumah mereka dan dilemparkan ke api unggun. Paus Klemens VI berusaha menghentikan kebrutalan itu tetapi suara-

${ }^{22}$ Norman F. Cantor, In the Wake of the Plague: The Black Death and the World It Made (New York: Simon and Schuster, Inc, 2011), 3.

${ }^{23}$ Cantor, In the Wake of the Plague, 3.

${ }^{24}$ Cantor, In the Wake of the Plague, 3.

${ }^{25}$ Mark Galli, "When a Third of the World Died," accessed April 30, 2020, https://www.christianitytoday.com/history/issues/issue-49/black-deathchristian-response-third-world-died.html. 
nya hampir tidak didengarkan. Beberapa ratus orang yahudi dibakar hidup-hidup dalam sebuah rumah kayu yang secara khusus dibangun untuk tujuan tersebut 2.000 orang Yahudi di kota Strasbourg, Prancis, dibawa ke pembantaian, di mana mere-ka dibakar hidup-hidup dalam barisan pasak. ${ }^{26}$

\section{Wabah Pes di Jerman, Swiss, dan Italia}

Sekitar 200 tahun setelah peristiwa black death atau kematian hitam, wabah pes (bubonic plague) yang dianggap sebagai kelanjutan dari black death, melanda kota Wiitenberg, Jerman tepatnya pada 2 Agustus 1527. Wabah ini dengan cepat membunuh banyak orang dengan rasa sakit tidak tertahan yang ditandai dengan demam tinggi dan borok atau bisul yang menyakitkan pada kulit. ${ }^{27}$ Wabah yang sama juga melanda kota Zurich, Swiss beberapa tahun sebelumnya, tepatnya bulan Agustus 1519. Wabah tersebut tercatat menyebabkan lebih dari seperempat populasi di kota Zurich terjangkit oleh wabah. ${ }^{28}$ Tidak hanya Zurich, kota lain di Swiss yaitu Jenewa juga mengalami wabah berikutnya pada tahun 1542 . Wabah ini muncul berulang kali di sejumlah wilayah di Eropa karena keterbatasan pengetahuan medis terkait pandemi. ${ }^{29}$

Wabah pes juga terjadi di kota Milan, Italia pada tahun 1629-1631 dan pada tahun 1576-1578. Pada wabah pertama penyakit ini diduga disebarkan oleh para tentara Jerman dan Perancis yang masuk ke daerah tersebut karena buruknya sanitasi. Total kematian pada wabah pertama hingga 60.000

${ }^{26}$ Galli, "When a Third of the World Died," diakses pada 30 April 2020, https://www.christianitytoday.com/history/issues/issue-49/black-deathchristian-response-third-world-died.html.

${ }^{27}$ Martin Luther, "Whether One May Flee from a Deadly Plague," Luther's Works: Devotional Writings 2, no. 43 (1989): 113-138.

${ }^{28}$ John D. Woodbridge and Frank A. James III, Church History, Volume Two: From Pre-Reformation to the Present Day: The Rise and Growth of the Church in Its Cultural, Intellectual, and Political Context (Grand Rapids: Zondervan, 2013), 65.

${ }^{29}$ John D. Witvielt, "Pandemics and Public Worship Throughout History," accessed April 30, 2020, https://worship.calvin.edu/resources/ resource-library/pandemics-and-public-worship-throughout-history. 
orang yang meninggal. ${ }^{30}$ Pada tahun 1576-1578 menjadi wabah kedua yang kembali datang dan melumpuhkan kota Milan. Hal ini menyebabkan pemerintah setempat mengeluarkan strategi pembatasan bagi setiap orang yang tengah melakukan perjalanan dan perdagangan, di duga terinfeksi, dan terinfeksi untuk di isolasi dalam Rumah Sakit. 1/6 populasi kota Milan dilaporkan meninggal karena kasus ini. ${ }^{31}$

\section{Respons Bapa-Bapa Gereja atas Pandemi yang Terjadi dari Masa ke Masa}

Pandemi yang terjadi di sepanjang sejarah gereja menghasilkan sejumlah respons dari orang-orang Kristen, secara khusus pemuka agama yang menonjol saat itu. Para pemuka agama tersebut dikenal dengan sebutan Bapa-bapa gereja. Beberapa orang bapa gereja yang pernah mengalami atau terlibat langsung dengan pandemi tersebut misalnya Dionysius, Cyprianus, Marthin Luther, Ulrich Zwingli, John Calvin, dan Carlo Borromeo. Para bapa gereja ini mengambil sejumlah langkah strategis sebagai upaya menyelamatkan kota dari ancaman wabah. Tindakan mereka mengutamakan keselamatan orang banyak, baik Kristen maupun nonKristen. Mereka juga mengatur persoalan ibadah atau misa dengan sebaik mungkin, sambil mengupayakan physical distancing namun tidak abai kepada mereka yang telah terjangkit wabah tersebut.

\section{Dionysius, Uskup Aleksandria}

Uskup Dionysius dari Aleksandria menulis bahwa banyak orang mengabaikan bahkan menelantarkan dan membuang keluarganya yang terkena wabah. Mereka dibuang ke jalan sebelum mati dan memperlakukan mayat-mayat yang tidak dikubur sebagai kotoran. Berbeda dengan sikap kebanyakan orang, bagi Dionysius, wabah itu berfungsi sebagai "sekolah dan ujian" bagi orang Kristen. Dionysius menyerukan agar orang-orang Kristen

${ }^{30}$ Samuel K Cohn, Jr., Cultures of Plague: Medical Thinking at the End of the Renaissance (Oxford: Oxford University Press, 2011), 114.

${ }^{31}$ Guido Alfani, "Plague," in Calamities and the Economy in Renaissance Italy (London: Palgrave Macmillan, 2013), 79-111. 
pada masa itu tetap memperhatikan orang lain yang menderita sambil menjaga diri sendiri. Tanpa menghiraukan bahaya, orangorang Kristen mulai mengambil alih orang sakit, merawat, memperhatikan setiap kebutuhan mereka. Bahkan beberapa dari mereka terinfeksi dan akhirnya meninggal, tetapi mereka dengan senang hati menerima kesakitan mereka. ${ }^{32}$ Tindakan tersebut kerap dianggap sebagai aksi konyol dan bunuh diri sebab jumlah umat Kristen pada masa itu tidak sampai 2\% dari jumlah penduduk Romawi. Ditambah dengan fakta bahwa orang Kristen tidaklah kebal terhadap pandemi tersebut. Akan tetapi, pelayanan beresiko yang mereka lakukan berhasil menyelamatkan banyak nyawa. Sejarawan mencatat bahwa wabah Cyprian memang memicu krisis yang luar biasa dalam sejarah Romawi, tetapi wabah itu juga turut ambil bagian dalam memicu ledakan pertumbuhan jumlah orang Kristen di Romawi yang akhirnya tersebar luas ke pelbagai penjuru Eropa. ${ }^{33}$

\section{Cyprianus, Uskup Kartago}

Cyprianus, Uskup Kartago menyebutkan bahwa justru faktor wabah membuat Kekristenan makin dikenal pada zaman itu. Penyebabnya adalah orang-orang Kristen tidak meninggalkan yang terinfeksi, bahkan para pengikut pagan yang selama ini mengolok dan menghina mereka. Banyak orang Kristen yang terinfeksi wabah, namun di tengah wabah tersebut justru mereka menemukan "kehidupan." Mereka menjadi lebih kuat sebagai bagian dari masyarakat, dan memiliki ketahanan lebih karena memiliki harapan yang kuat menghadapi kematian. Mereka lebih kuat sebagai komunitas dengan membangun ikatan yang lebih dekat melalui penderitaan yang mereka hadapi. Itu sebabnya angka kematian orang-orang Kristen pada zaman itu, menurut laporan Dionysius, lebih rendah daripada populasi umum. Mereka yang memberikan perawatan memiliki resiko infeksi yang lebih tinggi, tetapi di sisi lain, mereka yang terinfeksi memiliki tingkat kelangsungan hidup yang lebih baik. Dalam

\footnotetext{
${ }^{32}$ Stark, The Triumph of Christianity, 82.

${ }^{33}$ Stark, The Triumph of Christianity, 82.
} 
biografi Pontius tentang Cyprianus, uskup Kartago, ia menulis tentang bagaimana uskup mengingatkan orang-orang percaya untuk melayani tidak hanya sesama orang Kristen tetapi juga orang-orang non-Kristen selama wabah. ${ }^{34}$

\section{Martin Luther}

Tiga sosok dalam sejarah Reformasi Protestan yaitu Marthin Luther, Ulrich Zwingli, dan John Calvin memberikan contoh atau teladan di tengah pandemi yang pernah mereka hadapi. Saat wabah melanda Wittenberg dan seluruh penghuni kota diperintahkan untuk mengungsi, Marthin Luther memilih untuk tinggal melayani orang-orang sakit. Luther mengirimkan surat Pastoral kepada sahabatnya, Pastor Dr. John Hess saat wabah mematikan melanda kota Wittenberg:

Saya akan memohon belas kasihan Tuhan untuk melindungi kita.

Kemudian saya akan melakukan fumigasi, membantu membersihkan udara, memberikan obat-obatan dan mengambilnya. Saya akan menghindari tempat-tempat dan orang-orang di mana keberadaan saya tidak diperlukan agar tidak terkontaminasi dan dengan demikian dapat menimbulkan dan mencemari orang lain dan karenanya menyebabkan kematian mereka sebagai akibat dari kelalaian saya. Jika Tuhan ingin 'mengambil' saya, dia pasti akan menemukan saya dan saya telah melakukan apa yang Dia harapkan dari saya sehingga saya tidak bertanggung jawab baik atas kematian saya sendiri maupun kematian orang lain. Namun jika tetangga saya membutuhkan saya, saya tidak akan menghindari tempat atau orang tetapi saya akan pergi dengan bebas seperti yang disebutkan di atas. Lihatlah ini adalah iman yang takut akan Tuhan karena tidak kurang ajar dan tidak bodoh dan tidak mencobai Tuhan. "35

Dalam surat tersebut Luther menyampaikan pandangannya terkait beberapa hal. Pertama, tindakan menghindar dari wabah bukanlah tindakan yang kurang beriman melainkan salah satu pilihan yang bisa diambil untuk tidak tertular dan pada gilirannya

${ }^{34}$ Scrivener, "Pandemics and Public Worship Throughout History," diakses 30 April 2020, https://www.thegospelcoalition.org/article/4-lessonschurch-history/.

${ }^{35}$ Luther, "Whether One May Flee from a Deadly Plague." 114. 
berpotensi menularkan penyakit pada orang lain. Kedua, walaupun menyebut bahwa menyingkir bukanlah sikap yang tidak beriman, tetapi Luther juga kembali mengingatkan tanggung jawab sebagai umat Kristen, yaitu mewujudkan kasih melalui tindakan nyata dengan memperhatikan orang-orang lemah, khususnya yang terjangkit penyakit. Sikap Luther ini dipengaruhi oleh pembacaannya terhadap teks Matius 25:41-45.

Berdasarkan teks tersebut, Luther mengajukan pertanyaan reflektif untuk dirinya sendiri dan untuk umat Kristen pada masa itu: "Apa yang akan saya lakukan jika yang mengalami sakit dan yang terlantar itu adalah Yesus?" Salah satu ungkapan lain yang terkenal dari Luther adalah: "ekspresi perlakuan kita kepada sesama, sesungguhnya adalah perwujudan dari ekspresi perlakuan kita kepada Allah." Luther akhirnya memilih untuk bertahan di Wittenberg dan melayani umat di sana. Pada saat itu banyak orang menganggap enteng dan tidak mau meminum obat. Terhadap hal ini Luther berkata, "This is not trusting God, but tempting him. God has created medicines and provided us with intelligence to guard and take good care of the body so that we can live in good health". 36

\section{Ulrich Zwingli}

Zwingli sedang berlibur pada Agustus 1519, ketika black death pecah di Zurich. Meskipun sudah lemah karena pekerjaan yang melelahkan, ia bergegas kembali ke kotanya untuk melayani para korban. Ia tidak meninggalkan tugas pastoral meskipun dalam kondisi tubuh yang lemah. Tidak lama kemudian, dia sendiri terserang penyakit itu dan kondisi kesehatannya semakin memburuk. Tetapi ia merasa pekerjaannya belum selesai dan ternyata Zwingli pulih. Bahkan kemudian ia menciptakan lagu yang dikenal sebagai "nyanyian pujian wabah" atau plague hymn yang menguatkan banyak orang di saat wabah terjadi. ${ }^{37}$ Lagu

${ }^{36}$ Dean Philip Bell, Plague in the Early Modern World: A Documentary History (London: Routledge, 2019), 116.

${ }^{37}$ Woodbridge and James III, Church History, Volume Two: From PreReformation to the Present Day: The Rise and Growth of the Church in Its Cultural, Intellectual, and Political Context, 65. 
tersebut terdiri dari 8 bait. Bait 1-4 ditulis saat penyakit pertama kali menyerang sedangkan bait 5-8 diselesaikan ketika kesehatannya memburuk hingga kemudian pulih kembali. Berikut potongan 3 bait dari 8 bait lagu ciptaan Zwingli: Help me, O Lord, My strength and rock; Look, at the door, I hear death's knock. Uplift shine arm, Once pierced for me. That conquered death. And set me free. Yet, if thy voice, In life's midday. Recalls my soul, Then I obey. ${ }^{38}$

\section{John Calvin}

Selama pelayanan Calvin, Jenewa diteror oleh wabah pada 1542. Di tengah wabah tersebut, Calvin secara pribadi memimpin kunjungan ke rumah-rumah penduduk Jenewa yang terinfeksi wabah. Para pemimpin kota berusaha menghentikannya sebab hal tersebut berpotensi membuatnya dijatuhi hukuman mati karena melanggar aturan karantina. Namun Calvin tidak kehilangan akal dan ia berhasil menghimpun banyak tenaga sukarelawan untuk datang berkunjung meskipun dilakukan secara rahasia. Pada masa itu, banyak sukarelawan yang meninggal termasuk sahabat Calvin, Claude Ferey. ${ }^{39}$ Ia lakukan pelayanan pastoral yang pada gilirannya sukses menarik perhatian banyak orang untuk mengumpulkan sumbangan. Sumbangan tersebut untuk pembangunan rumah sakit bagi warga kota maupun para imigran. Calvin juga mengumpulkan sumber daya yang diperlukan untuk membangun rumah sakit terpisah untuk para korban wabah. Ketika orang-orang percaya mati, ia berkhotbah tentang homili-homili (renungan) yang menyedihkan namun disertai penghiburan, semangat dan kepedulian. ${ }^{40}$

${ }^{38}$ Janet Meyer Everts, "Black Death Inspires Zwingli’s Plague Hymn," accessed April 30, 2020, https:/www.christianitytoday.com/ history/issues/ issue-4/black-death-inspires-zwinglis-plague-hymn.html.

${ }^{39}$ Scott M. Manetsch, Calvin's Company of Pastors: Pastoral Care and the Emerging Reformed Church, 1536-1609, (Oxford: Oxford University Press, 2015), 284.

${ }^{40}$ Michael Mullet, John Calvin (London: Routledge, 2016), 128. 


\section{Carlo Borromeo}

Bapa Gereja ini lahir dari seorang bangsawan Milan. Carlo adalah anak kedua yang kehidupannya didedikasikan untuk pelayanan gerejawi secara total. Carlo lulus dari University of Pavia dari jurusan kanon dan hukum sipil pada tahun 1559 dan bertepatan dengan itu pamanya adalah Paus Pius ke IV. Carlo Borromeo terpilih menjadi uskup Milan yang ditabiskan pada tahun $1564 .{ }^{41}$ Carlo Borromeo melakukan peranan yang sangat penting dalam kehidupan kota Milan pasca wabah bubonic atau pes pada tahun 1576-1578. Bapa Gereja ini memberikan sumbangsih yang sangat penting dalam hal mengatur kesehatan masyarakat, perawatan sekuler dan pemenuhan kebutuhan rohani. Bapa Gereja ini memberikan semangat bagi seluruh warga Milan dengan mengatur strategi dalam memerangi wabah bubonic yang sedang berkecamuk. ${ }^{42}$ Di Kemudian hari, terbukti bahwa tindakannya tersebut sangat efektif di dalam menekan jumlah korban meninggal dunia akibat wabah mematikan tersebut.

Ketika Milan dilanda wabah pada 1576, Borromeo, Uskup Agung Keuskupan Ambrosian, mendesak para imam untuk membantu orang sakit. Sadar akan resiko penularan dan untuk menghindari dirinya menjadi faktor penyakit, ia menjaga jarak aman saat berbicara dengan orang lain. Dia sering mengganti pakaiannya dan mencucinya dengan air mendidih. Dia berusaha melakukan sterilisasi dengan api dan spons yang direndam dalam cuka yang selalu dia bawa. Ia juga memerintahkan agar misa hanya dihadiri oleh orang dewasa, membagi tempat menjadi 2 baris, dengan jarak tiga meter satu sama lain. Mereka yang diduga terinfeksi dan sakit, dilarang untuk mengikuti misa. Ia juga mengusulkan karantina umum untuk semua warga yang harus mengunci diri di rumah mereka selama 40 hari. Saat keadaan makin memburuk, pada 15 Oktober 1576, Pengadilan kota menerima proposal uskup Borromeo dan mengeluarkan

\footnotetext{
${ }^{41}$ Byrne, Encyclopedia of the Black Death, 56-57.

${ }^{42}$ Alfani, "Plague", 79.
} 
karantina umum untuk semua penduduk Milan. ${ }^{43}$ Tindakan Borromeo ini berhasil membuat kota tersebut selamat dari kemungkinan amukan wabah yang berpotensi dapat memusnahkan sebagian besar populasi di kota tersebut.

Carlo Borromeo juga mengingatkan warga kota Milan akan dosa. Hal ini dilakukan dengan cara dia melakukan prosesi membawa kayu salib besar di jalan kota Milan, sehingga para warga yang diam ketakutan di rumahnya masing-masing dapat beribadah melalui simbolisasi tersebut. Simbol tersebut menjadi semacam kekuatan bagi warga kota Milan dalam perjuangan melalui wabah tersebut. Carlo Borromeo tetap melayani dan mengabdi pada warga kota Milan yang masih tinggal di rumah masingmasing meski ia didesak untuk pergi dari kota Milan. ${ }^{44}$ Misa dilakukan secara unik demi kehidupan rohani para warganya di kota tersebut. Carlo Borromeo membagikan litani pujian bersahutan sehingga setiap warganya dapat memuji Tuhan dari kediamannya masing-masing saat prosesi ibadah berlangsung. ${ }^{45} \mathrm{War}-$ ga kota dapat tetap beribadah kepada Tuhan meskipun mengalami kendala dan harus memindahkan rutinitas ibadah mingguan ke rumah mereka masing-masing. Bapa Gereja Carlo Borromeo merupakan teladan yang memberikan contoh dalam menghadapi wabah ini tanpa kehilangan sedikitpun nilai-nilai hospitalitasnya.

\section{Pelajaran dari Sejarah Gereja: Antara Karantina dan Hospitalitas yang Beresiko}

Pandemi yang terjadi di sepanjang sejarah gereja, berhasil dilalui meskipun menimbulkan banyak korban jiwa. Sejarah gereja memperlihatkan sejumlah pelajaran yang dapat dipetik untuk kehidupan saat ini termasuk menerapkan karantina dan isolasi di kala pandemi berkecamuk. Selain karantina, sejarah

43،"Epidemics, Quarantines, Empty Churches: Historical Precedents," accessed April 30, 2020, https://www.vaticannews.va/en/vatican-city/news/ 2020-04/epidemics-quarantines-empty-churches-history-tornielli.html.

${ }^{44}$ Byrne, Encyclopedia of the Black Death.

${ }^{45} \mathrm{R}$. Chiu, "Singing on the Street and in the Home in Times of Pestilence: Lessons from the 1576-78 Plague of Milan," Domestic Devotions in Early Modern Italy Brill (2018): 27-44. 
gereja juga memperlihatkan bagaimana respons orang-orang Kristen yang mengutamakan kepedulian kepada sesama yang terjangkit, kendati hal tersebut sangat beresiko. Orang-orang Kristen pada saat itu menerapkan hospitalitas atau keramahtamahan di tengah situasi yang mencekam. Karantina dan hospitalitas tersebut menjadi usaha yang dilakukan demi merawat kehidupan dan sekaligus bersama-sama menghadirkan kasih dan solidaritas yang terwujud nyata melalui tindakan.

\section{Sejarah Istilah "Karantina"}

Kata karantina (quarantine) berasal dari bahasa Italia, quarantina dan quaranta giorni. Istilah tersebut menunjuk pada periode 40 hari kapal-kapal memasuki pelabuhan Venice; kapalkapal tersebut menjalani isolasi sebelum barang-barang, kru, dan penumpang diizinkan untuk keluar selama berkembangnya wabah yang berlangsung pada abad ke-14 dan ke-15. Sekitar tahun 1374, Venice memberlakukan peraturan karantina selama 40 hari. 29 tahun kemudian pada 1403, kota tersebut membangun pusat karantina maritim pertama atau lazaretto di Pulau Santa Maria di Nazareth. ${ }^{46}$ Karantina menjadi satu-satunya cara paling efektif pada konteks zaman itu untuk mencegah penyebaran wabah ke penjuru kota sekaligus menekan jumlah korban yang berjatuhan akibat wabah yang berkecamuk tersebut.

Dari perspektif Islam, ide tentang karantina disebut-sebut sudah ada sejak zaman Nabi Muhammad. Saat terjadi wabah kusta atau lepra yang mematikan, Nabi Muhammad memerintahkan untuk melakukan isolasi agar pandemi tersebut tidak menyebar dan menginfeksi daerah lain. Bahkan, Nabi Muhammad memerin-tahkan untuk membangun tembok pembatas di sekitar wilayah yang terkena wabah. "Jika kalian mendengar wabah terjadi di suatu wilayah, janganlah kalian memasuki wilayah tersebut. Sebaliknya jika wabah itu terjadi di tempat kalian tinggal, jangan-lah kalian meninggalkan tempat itu" (HR. Al-

${ }^{46}$ Howard Markel, Quarantine!: East European Jewish Immigrants and the New York City Epidemics of 1892 (Baltimore: Johns Hopkins University, 1999), 9. 
Bukhari). ${ }^{47}$ Hal ini memperlihatkan bahwa dalam sejarahnya, umat Islam juga pernah berhadapan dengan persoalan tersebut dan menemukan solusi atas hal tersebut.

\section{Sejarah Istilah Hospitalitas}

Hospitalitas dalam sejarahnya merupakan suatu bentuk keramahtamahan yang dilakukan oleh seorang tuan rumah kepada pengembara yang membutuhkan tempat bernaung. Tuan rumah menyediakan perlindungan dan makanan sedangkan bentuk terimakasih dari pengembara adalah memberikan cerita pengalamannya kepada pemilik rumah. ${ }^{48}$ Relasi timbal balik tersebut membuat persaudaraan dan persahabatan terjalin antara orang asing dan sang pemilik rumah. Hospitalitas adalah kewajiban kultural atau adat istiadat bagi orang-orang di zaman kuno, termasuk bangsa Israel kuno. Salah satu contoh terkenal dalam Kitab Suci adalah tindakan Abraham yang menjamu tiga tamu asing dengan ramah tamah dalam Kejadian 18. Abraham tidak mengenal ketiga tamu asing yang sebenarnya adalah penjelmaan dari malaikat utusan Tuhan. Namun keramahtamahan yang dilakukan oleh Abraham kepada ketiga tamu asing tersebut membuatnya diperkenan oleh Allah dan ia mendapatkan janji bahwa ia akan memperoleh keturunan. Bahkan dalam Kitab Ayub juga mengindikasikan bahwa praktik keramahtamahan sudah ditemukan jejaknya dalam Kitab Suci, "malah orang asing pun tidak pernah bermalam di luar, pintuku kubuka bagi musafir". Sikap ini merupakan sikap dasar yang harus dimiliki oleh orang Kristen sebagai wujud dan bukti kasihnya kepada sesama manusia. Setiap orang Kristen harus memiliki sikap hospitalitas sebagai bentuk ucapan syukur terhadap kasih karunia yang diberikan Tuhan di dalam hidupnya. ${ }^{49}$ Ucapan syukur tersebut sebenarnya adalah salah satu bentuk respons manusia atas kebaikan Tuhan yang telah lebih dahulu dinyatakan kepada mereka. Perbuatan

${ }^{47}$ Alfiyah Kharomah, "Cara Islam Selesaikan Pandemi Covid-19," accessed April 30, 2020, https://www.galamedianews.com/?arsip= 250218 \&judul=cara-islam-selesaikan-pandemi-covid-19.

${ }^{46}$ Hershberger, Hospitalitas, 4.

${ }^{49}$ Lee Roy Martin, "Old Testament Foundations for Christian Hospitality," Verbum et Ecclesia 35, no. 1 (2014): 1-9. 
baik kepada sesama termasuk orang asing sesungguhnya merupakan perwujudan dari bakti kepada Sang Pencipta.

Christine D. Pohl menegaskan bahwa usaha membukakan pintu atau menerima orang asing masuk ke rumah dan memberikan mereka makanan, tempat bernaung dan perlindungan merupakan unsur utama dalam praktik hospitalitas. Akan tetapi, pemaknaan hospitalitas demikian saat ini telah mengalami pergeseran dan degradasi yang membuatnya kehilangan kekayaan makna dan kompleksitas tradisinya. Hospitalitas saat ini justru lebih banyak dihubungkan dengan dunia industri, perhotelan, restoran yang menyambut orang asing hanya jika mereka memiliki uang atau kartu kredit. Pada titik ini, hospitalitas yang autentik menjadi sekadar slogan kosong karena memiliki kecenderungan untuk mengeruk keuntungan di bidang industri atau ladang bisnis. ${ }^{50}$ Hospitalitas dalam konteks ini tidak lebih dari usaha mengeksploitasi dan memanfaatkan momen untuk kepentingan pribadi, dengan mengabaikan kasih dan kepedulian kepada orang lain yang membutuhkan.

Hospitalitas semestinya dipahami sebagai salah satu bentuk sikap kasih yang tampak melalui penyambutan dan penerimaan yang tulus terhadap mereka yang dianggap sebagai orang asing atau pendatang. Hal ini sekaligus berarti bahwa hospitalitas yang sejati ditunjukkan dengan cara menyalami, menerima, menampung, bahkan memberi makan dengan cuma-cuma kepada orang miskin, orang asing, para pendatang ataupun para peziarah. Oleh karena itu, hospitalitas merupakan perwujudan konkret dari sebuah perhatian serta tanggung jawab terhadap sesama manusia. ${ }^{51}$ Tanggung jawab tersebut diperlihatkan lewat tindakan nyata dan konkret untuk menjunjung tinggi nilai-nilai kemanusiaan sebagai sesama makhluk ciptaan Tuhan.

Hopitalitas akan menuntun kehidupan orang percaya pada suatu bentuk keamanan. Hospitalitas juga dapat menjalin persahabatan dari tantangan-tantangan eksternal yang ada. Hospitali-

${ }^{50}$ Christine D. Pohl, Making Room: Recovering Hospitality as a Christian Tradition (Grand Rapids: Eerdmans publishing Company, 1999), 4.

${ }^{51}$ Felix Baghi, Alteritas: Pengakuan, Hospitalitas, Persahabatan (Etika Politik Dan Postmodernisme) (Maumere: Ledalero, 2012), 92. 
tas menawarkan bentuk yang tepat bagi kehidupan antaragama. ${ }^{52}$ Hospitalitas juga menawarkan bentuk kerukunan pada kasuskasus kekerasan dalam agama. ${ }^{53}$ Kekerasan antarumat beragama yang kerap kali terjadi di Indonesia dapat dicegah dengan mengedepankan sikap hospitalitas yang autentik tanpa membedabedakan manusia. Hal ini yang menjadikan dasar pentingnya hospitalitas yang harus dikerjakan oleh umat manusia di tengah terjadinya pandemi. Berdasarkan hal tersebut dan melihat dari kebaikan-kebaikan yang ditawarkan oleh bentuk tersebut, namun hospitalitas juga memiliki sejumlah resiko.

\section{Karantina dan Hospitalitas untuk Merawat Kehidupan di Tengah Pandemi Covid-19}

Bagaimana dengan konteks di tahun 2020 hingga 2021 saat dunia berhadapan dengan pandemi Covid-19? Pelajaran apa yang dapat dipetik dari orang-orang Kristen saat menghadapi wabah di masa lalu? Sejarah pandemi memperlihatkan bahwa pandemi pasti berlalu, berapapun lamanya pandemi tersebut berlangsung. Artinya untuk konteks saat ini tersedia harapan yang sama bahwa pandemi Covid-19 juga niscaya akan berlalu, meski belum diketahui secara pasti kapan pandemi dan efek yang menyertainya akan berlalu.

Selanjutnya, fakta sejarah yang diungkapkan lewat pelbagai kasus pandemi yang terjadi memperlihatkan bahwa respons gereja atau umat Kristen tidak selalu tepat dan bijak saat menghadapi pandemi. Misalnya saja yang terjadi dalam kasus persekusi dan pembunuhan kepada orang Yahudi pada saat terjadi wabah black death tahun 1348-1350 yang dituduh sebagai biang keladi terjadinya wabah. Hal ini menunjukkan bahwa ajaran Kristiani tentang kasih dan solidaritas tidak selalu mampu diterapkan oleh mereka di kala kepanikan melanda. Hal ini

${ }^{52}$ Mariani Febriana, "Hospitalitas: Suatu Kebajikan Yang Terlupakan Di Tengah Maraknya Aksi Hostilitas Atas Nama Agama," Jurnal Theologia Aletheia 20, no. 14 (2018): 57-96.

${ }^{53}$ Yohanes K. Susanta, "Hospitalitas Sebagai Upaya Mencegah Kekerasan Dalam Memelihara Kerukunan Dalam Relasi Islam - Kristen Di Indonesia," Societas Dei: Jurnal Agama dan Masyarakat 2, no. 1 (October 24, 2017): 281-312, http://societasdei.rcrs.org/index.php/SD/article/view/62. 
menjadi pelajaran penting sekaligus menunjukkan bahwa umat beragama kerap kali menunjukkan wajah lain dari agama itu sendiri; bukan wajah kedamaian melainkan wajah kekerasan. Wajah kekerasan itu yang kerapkali masih ditemui saat ini. Saat wabah virus Corona melanda kota Wuhan, China, beberapa orang bahkan mengklaim bahwa hal tersebut adalah azab dari Tuhan. ${ }^{54}$ Suatu sikap beragama yang diskriminatif, menganggap diri paling benar, tertutup dan jauh dari empati dan solidaritas kemanusiaan. Sikap beragama yang demikian ternyata juga mewarnai sejarah kekristenan itu sendiri. Benih-benih permusuhan dan tindakan menyalahkan pihak lain atas peristiwa yang terjadi bukanlah sikap ksatria dan dapat dibenarkan dalam ajaran agama apapun juga. Dalam konteks Indonesia di masa kini, sikap demikian bahkan merupakan pelanggaran dari salah satu sila dari Pancasila, kemanusiaan yang adil dan beradab.

Di tengah pandemi Covid-19 yang berlangsung sejak akhir tahun 2019, tentu saja ada pelajaran penting dari segi positif yang dapat diteladani dari sejarah gereja dalam menangani wabah. Dalam konteks zaman itu, tenaga medis dan pengetahuan medis masih terbatas sehingga tindakan sejumlah umat Kristen dapat disebut sebagai kebodohan dari perspektif modern. Akan tetapi, pelajaran yang dapat dipetik dari sikap mereka di masa lampau terkait semangat yang tidak hanya mengutamakan kepentingan diri sendiri, tetapi kepentingan orang lain juga termasuk yang berbeda keyakinan. Suatu contoh sikap beragama yang dilandasi dengan solidaritas sosial yang tinggi, yang melampaui batas dan tembok beragama yang eksklusif. Sikap sejumlah orang Kristen yang berani mengambil resiko, bahkan mempertaruhkan nyawa demi menyelamatkan banyak orang yang terkena wabah adalah teladan yang patut untuk diikuti. Tindakan heroik tersebut adalah perwujudan dari sikap memperlakukan orang lain sebagaimana diri sendiri ingin diperlakukan. Tindakan tersebut menjadi pelajaran penting bagi kehidupan masa kini

\footnotetext{
${ }^{54}$ Dani Garjito, "Teguran Cucu Nabi Muhammad Ke Muslim Yang Sebut Virus Corona Azab China," diakses 30 April 2020, https://www.suara.com/news/2020/02/11/123748/teguran-cucu-nabimuhammad-ke-muslim-yang-sebut-virus-corona-azab-china.
} 
yang cenderung abai terhadap kepentingan bersama karena lebih menonjolkan sikap egois dan individualistik.

Teolog modern Jurgen Moltmann, sebagaimana dikutip oleh Peter Slade, pernah mengusulkan model kehidupan beragama yang seharusnya dilandasi dengan semangat cinta kasih dan persahabatan. Hal ini sesuai dengan ajaran Yesus yang tercatat dalam kitab Injil, misalnya "Kasihilah sesamamu manusia seperti dirimu sendiri" (Mrk. 12:31), serta "Tidak ada kasih yang lebih besar dari pada kasih seorang yang memberikan nyawanya untuk sahabat-sahabatnya" (Yoh. 15:13). ${ }^{55}$ Dalam konteks Covid-19, adakah yang bersedia menerapkan ajaran Kristus yaitu mengamalkan kasih terbesar dengan cara rela berkorban dan memberi nyawa untuk para sahabat? Dalam konteks Covid-19, saat ada orang lain yang terpapar penyakit, bukan tindakan bully atau mengucilkan yang diperlukan melainkan tindakan kepedulian. Selain itu, sikap saling mendukung, menghibur dan memberikan dorongan positif kepada para korban merupakan sikap yang diperlukan dalam usaha melewati pandemi ini. Karantina dan hospitalitas yang beresiko adalah pelajaran lain yang dapat dipetik dari tradisi Kristen saat menghadapi pandemi dari masa ke masa.

Dari sosok Bapa Gereja, Marthin Luther, terdapat pelajaran bahwa sejak masa lampau, strategi-strategi dalam memerangi wabah seperti fumigasi, pengasapan, dan pemurnian udara sudah dilakukan. Bahkan apa yang saat ini dikenal dengan istilah social distancing juga sudah diterapkan oleh Luther dan Barromeo, termasuk dalam hal ibadah di rumah masing-masing. Karantina hanyalah salah satu cara untuk menekan dan memutus rantai penyebaran wabah, termasuk dalam kasus Covid-19. Akan tetapi karantina bukanlah satu-satunya cara, sebagaimana yang disarankan dan dilakukan oleh Bapa-Bapa gereja di masa lampau. Ketika wabah sudah menjangkiti orang lain, maka sudah merupakan tugas dan panggilan kemanusiaan untuk menolong orang tersebut sambil tetap menjaga diri sendiri agar tidak tertular dan

${ }^{55}$ Han Luen Kantzer Komline, "Friendship and Being: Election and Trinitarian Freedom in Moltmann and Barth," Modern Theology, 2013: 87, https://doi.org/10.1111/moth.12000. 
menjadi sumber penularan. Inilah yang disebut sebagai hospitalitas atau keramahtamahan yang beresiko. Resiko untuk tertular (jika memang orang tersebut membawa wabah) memang ada, akan tetapi diperlukan keberanian untuk mengambil resiko tersebut. Tanpa keberanian tersebut, adagium bahwa manusia adalah makhluk sosial yang senantiasa memerlukan orang lain, akan menjadi tidak berarti.

Hospitalitas harus diakui merupakan konsep ideal yang kerap kali masih jauh dari praktiknya di lapangan. Sebagaimana telah dijabarkan dalam tulisan ini bahwa hospitalitas adalah suatu gaya hidup yang sudah diterapkan di sepanjang sejarah kekristenan. Christine D. Pohl menjelaskan bahwa dalam sejarah gereja, keramahtamahan dipahami mencakup fisik, sosial, dan spiritual dari dimensi keberadaan dan hubungan antar manusia. Artinya bukan sekadar pemenuhan kebutuhan fisik orang asing untuk makanan, tempat tinggal, dan perlindungan, tetapi juga pengakuan atas nilai kemanusiaan mereka. ${ }^{56}$

Pada praktiknya, hospitalitas masih sulit diterapkan. Hal ini tidak mengherankan sebab dalam masyarakat sendiri telah terekonstruksi paradigma yang menyebut orang lain, orang asing sebagai bahaya atau ancaman. Orang lain yang berbeda bahkan dalam konteks tertentu tidak diharapkan kehadirannya dan berupaya untuk disingkirkan. Di pelbagai tempat umum di Indonesia seperti terminal, stasiun, bandara, dan pusat perbelanjaan, kita seringkali melihat poster, banner, atau pengumuman agar kita berhati-hati dengan orang yang tidak kita kenal. Hal ini menunjukkan bahwa masyarakat sudah diwarnai oleh sikap xenophobia, ketakutan terhadap orang asing atau tamu yang tidak dikenal. Tulisan ini memperlihatkan bahwa ketakutan yang berlebihan dan berujung pada penolakan terhadap orang asing (baca: pende-rita Covid-19) bertentangan dengan sikap Allah yang memper-lakukan orang asing dengan ramah dan penuh belas kasih.

${ }^{56}$ Christine D. Pohl, Making Room: Recovering Hospitality as a Christian Tradition (Grand Rapids: Eerdmans publishing Company, 1999), 6. 
Dalam konteks pandemi, ada banyak contoh di mana manusia menunjukkan sikap ironis yaitu tatkala ada seseorang yang jatuh di jalan atau tempat umum, mengalami kejang dan sekarat, masyarakat justru menjauh dan enggan menolong. Perlu waktu berjam-jam lamanya hingga tim medis datang ke lokasi kejadian. Di satu sisi, tindakan masyarakat tersebut dapat dimaklumi sebagai langkah preventif, akan tetapi di sisi yang lain, masyarakat tetap bisa menolong dengan cara segera memanggil pihak berwenang atau jika memungkinkan, mencoba menolong sambil memperlengkapi diri dengan sejumlah pengaman (masker, face shield) yang dimiliki. Hal ini memang bukanlah perkara yang mudah. Akan tetapi jika hal ini terus menerus dipelihara, maka sikap acuh, egois, dan tidak peduli akan semakin mewarnai kehidupan masyarakat modern. Tidak menutup kemungkinan jika sikap ini terus dipelihara, suatu saat dengan mudah akan dijum-pai banyak mayat bergelimpangan di jalan dan hal itu akan dianggap sebagai suatu hal yang lumrah dan biasa.

Di tengah dunia yang sarat dengan individualisme dan pementingan diri sendiri, orang Kristen dan juga umat beragama lainnya dipanggil untuk mewujudkan kehidupan yang peduli kepada sesama manusia. Secara khusus dalam konteks Kristen, Hershberger menyebut bahwa keramahtamahan atau hospitalitas bukan sekadar kewajiban melainkan panggilan iman Kristiani untuk melayani sesama sebagai perpanjangan tangan Tuhan di dunia ini. ${ }^{57}$ Panggilan Kristiani ini tentu saja tidak hanya berlaku untuk sesama orang-orang Kristen saja, melainkan kepada semua umat manusia tanpa terkecuali.

Pelbagai bentuk hospitalitas sudah banyak dipraktikkan di tengah pendemi Covid-19, misalnya pemberian bantuan masker, penggalangan dana untuk para penderita dan juga tenaga medis. Akan tetapi hal tersebut harus dibarengi dengan keramahtamahan otentik. Bukan sekadar aksi sosial musiman atau mengikuti tren dan viral dan bahkan untuk sekadar mencari simpati publik di tengah pandemi. Tradisi gereja di masa lampau menunjukkan contoh hospitalitas yang otentik itu dengan meletakkan kepentingan umum (orang banyak) lebih utama daripada kepentingan

${ }^{57}$ Hershberger, Hospitalitas, 206. 
pribadi, termasuk dengan mempertaruhkan nyawa demi menolong orang lain yang menderita. Memberlakukan keramahtamahan yang otentik ini sejalan dengan prinsip bahwa hospitalitas Ilahi sesungguhnya tercermin dalam hospitalitas insani.

Karantina dan hospitalitas acapkali dianggap sebagai hal yang berkebalikan satu dengan lainnya di masa pandemi. Akan tetapi, dua hal ini tidak dapat dipisahkan dalam rangka merawat kehidupan umat manusia yang terdampak pandemi. Kedua sikap tersebut harus saling melekat dan harus dimiliki oleh setiap orang dalam menjalani kehidupannya di tengah masa pandemi. Keduanya memiliki resiko, akan tetapi sebagai orang yang telah menghargai hidup sebagai anugerah, setiap orang harus dapat mengimplementasikan sikap tersebut dalam kehidupan seharihari secara otentik dan holistik. Implementasi karantina secara konsekuen dan hopitalitas secara otentik dengan tujuan utama untuk memerangi pandemi penyakit yang sedang berkecamuk. Karantina dan hopitalitas yang dilakukan merupakan sebuah refleksi sikap sebagai bentuk ungkapan syukur kepada Sang Pencipta karena anugerah yang diberikan-Nya dengan merawat kehidupan manusia secara menyeluruh karena dampak pandemi.

\section{PENUTUP}

Tulisan ini membahas pentingnya sikap yang saling berkebalikan di tengah masa pandemi yaitu karantina dan hospitalitas untuk merawat kehidupan di tengah masa pandemi. Berdasarkan kajian historisitas sejarah Gereja dan respons Bapa-Bapa Gereja dapat disimpulkan bahwa sikap karantina dan hospitalitas merupakan sikap yang secara holistik dilakukan oleh Bapa-Bapa Gereja dalam menghadapi pelbagai pandemi yang mengancam kehidupan manusia pada zamannya. Sikap tersebut bertujuan merawat kehidupan manusia demi menegakkan nilai-nilai kemanusiaan sekaligus sebagai wujud solidaritas sebagai sesama makhluk ciptaan.

Simpulan tulisan ini, Pertama, respons orang-orang Kristen terdahulu dalam menanggapi wabah di masa lampau adalah bermacam-macam. Ada yang cenderung abai bahkan menyalahkan pihak lain seperti halnya orang Yahudi yang 
kemudian menjadi kambing hitam saat itu. Akan tetapi, sebagian besar dari orang-orang Kristen awal justru mengambil langkah radikal, yaitu mengambil resiko dengan tetap menaruh perhatian dan menolong sesama yang terpapar pandemi. Akibatnya, banyak dari orang-orang Kristen awal yang ikut tertular dan mati.

Kedua, gereja awal, khususnya melalui Bapa-Bapa gereja mengajarkan kepada kita beberapa hal sehubungan dengan pandemi Covid-19 yang dihadapi saat ini. Praktik karantina, social distancing, protokol kesehatan dengan cuci tangan serta hospitalitas adalah beberapa contoh di masa lampau yang telah dilakukan oleh Bapa-Bapa gereja. Seharusnya praktik tersebut dapat menginspirasi untuk kondisi saat ini yang masih bergumul dengan pandemi Covid-19. Sebab hanya dengan mengikuti aturan pemerintah secara disiplin dan bertanggung jawab, kita akan ikut bersumbangsih bagi usaha menekan dan melawan penyebaran Covid-19 sampai vaksin dari virus ini benar-benar terealisasi dan dinikmati masyarakat luas. 
KARANTINA DAN HOSPITALITAS YANG BERESIKO SEBAGAI RESPONS GEREJA DI SEPANJANG SEJARAH PANDEMI Yohanes Krismantyo Susanta, dan Daniel Fajar Panuntun.

\section{DAFTAR PUSTAKA}

\section{Buku}

Alfani, Guido. "Plague." In Calamities and the Economy in Renaissance Italy, 79-111. London:Palgrave Macmillan, 2013.

Baghi, Felix. Alteritas: Pengakuan, Hospitalitas, Persahabatan (Etika Politik Dan Postmodernisme). Maumere: Ledalero, 2012.

Bell, Dean Philip. Plague in the Early Modern World: A Documentary History. London: Routledge, 2019.

Byrne, Joseph P. Encyclopedia of the Black Death. California: Library of Congress Cataloging-in-Publication Data, 2012.

Cantor, Norman F. In the Wake of the Plague: The Black Death and the World It Made. New York: Simon and Schuster, Inc, 2011.

Cohn, Jr., Samuel K. Cultures of Plague: Medical Thinking at the End of the Renaissance. Oxford: Oxford University Press, 2011.

Concannon, Cavan W. Assembling Early Christianity: Trade, Networks, and the Letters of Dionysius of Corinth. Cambridge: Cambridge University Press, 2017.

Hershberger, Michele. Hospitalitas Orang Asing: Teman Atau Ancaman. Jakarta: BPK Gunung Mulia, 2009.

Lapan, Stephen D., MaryLynn T. Quartaroli, and Frances J. Riemer. Qualitative Research: An Introduction to Methods and Designs. New York: Jossey-Bass, 2012.

Lumintang, Stevri Indra dan Danik Astuti Lumintang. Theologia Penelitian Dan Penelitian Theologis Science-Ascience Serta Metodologinya. Jakarta: Geneva Insani Indonesia, 2016.

Manetsch, Scott M. Calvin's Company of Pastors: Pastoral Care and the Emerging Reformed Church, 1536-1609,. Oxford: Oxford University Press, 2015. 
Markel, Howard. Quarantine!: East European Jewish Immigrants and the New York City Epidemics of 1892. Baltimore: Johns Hopkins University, 1999.

Mullet, Michael. John Calvin. London: Routledge, 2016.

Pohl, Christine D. Making Room: Recovering Hospitality as a Christian Tradition. Grand Rapids: Eerdmans publishing Company, 1999.

Ponsonby, Simon. Loving Mercy: How to Serve a TenderHearted Saviour. Oxford: Monarch Books, 2012.

Sherman, Irwin W. The Power of Plagues. Washington: ASM Press, 2017.

Stark, Rodney. The Triumph of Christianity: How the Jesus Movement Became the World's Largest Religion. United States: Harper Collins, 2011.

Wagiran. Metodologi Penelitian Pendidikan: Teori Dan Implementasi. Yogyakarta: deepublish, 2019.

Woodbridge, John D., and Frank A. James III. Church History, Volume Two: From Pre-Reformation to the Present Day: The Rise and Growth of the Church in Its Cultural, Intellectual, and Political Context. Grand Rapids: Zondervan, 2013.

\section{Jurnal Ilmiah}

Adhikari, Sasmita Poudel, et al. "Epidemiology, Causes, Clinical Manifestation and Diagnosis, Prevention and Control of Coronavirus Disease (COVID-19) during the Early Outbreak Period: A Scoping Review." Infectious Diseases of Poverty 9, no. 1 (2020): 1-12.

Chiu, R. "Singing on the Street and in the Home in Times of Pestilence: Lessons from the 1576-78 Plague of Milan." Domestic Devotions in Early Modern Italy Brill (2018): 2744.

Dwiraharjo, Susanto. "Konstruksi Teologis Gereja Digital: Sebuah Refleksi Biblis Ibadah Online Di Masa Pandemi Covid-19." EPIGRAPHE: Jurnal Teologi Dan Pelayanan 
Kristiani 4, no. 1 (2020): 1-17.

Eliman, Eliman, and Aris Elisa Tembay. "Pelayanan Pastoral Bagi Kaum Lansia Ditengah Pandemi Covid-19." Scripa: Jurnal Teologi Dan Pelayanan Kontekstual 9, no. 1 (2020): 48-68.

Febriana, Mariani. "Hospitalitas: Suatu Kebajikan Yang Terlupakan Di Tengah Maraknya Aksi Hostilitas Atas Nama Agama." Jurnal Theologia Aletheia 20, no.14 (2018):57-96.

Komline, Han Luen Kantzer. "Friendship and Being: Election and Trinitarian Freedom in Moltmann and Barth." Modern Theology, 2013.

Luther, Martin. "Whether One May Flee from a Deadly Plague." Luther's Works: Devotional Writings 2, no. 43 (1989): 11338.

Martin, Lee Roy. "Old Testament Foundations for Christian Hospitality." Verbum et Ecclesia 35, no. 1 (2014): 1-9.

Sabbatani, S., and S. Fiorino. "The Antonine Plague and the Decline of the Roman Empire." Le Infezioni in Medicina: Rivista Periodica Di Eziologia, Epidemiologia, Diagnostica, Clinica e Terapia Delle Patologie Infettive 17, no. 4 (2009): 261-275.

Susanta, Yohanes K. "Hospitalitas Sebagai Upaya Mencegah Kekerasan Dalam Memelihara Kerukunan Dalam Relasi Islam - Kristen Di Indonesia." Societas Dei: Jurnal Agama Dan Masyarakat 2, no. 1 (October 24, 2017): 281-312.

Susanta, Yohanes Krismantyo, and Daniel Fajar Panuntun. "Tinjauan Etika Kristen Atas Fenomena Disaster Joke Terkait Pandemi Covid-19." HARVESTER: Jurnal Teologi Dan Kepemimpinan Kristen 5, no. 1 (2020): 14-27.

Yeomans, Sarah K. "The Antonine Plague and the Spread of Christianity." Biblical Archaeology Review, 2017, 22-23. 


\section{Website}

"Epidemics, Quarantines, Empty Churches: Historical Prece-dents." diakses 30 April, 2020. https://www.vatican-news. $\mathrm{va/en/vatican-city/news/2020-04/epidemics-quarantines-}$ empty-churches-history-tornielli.html.

Everts, Janet Meyer. "Black Death Inspires Zwingli's Plague Hymn." diakses 30 April 2020. https://www.christianity today.com/history/issues/issue-4/black-death-inspires-zwinglisplague-hymn.html.

Galli, Mark. "When a Third of the World Died." diakses 30 April 2020.https://www.christianitytoday.com/history/issues/issue49/black-death-christian-response-third-world-died.html.

Garjito, Dani. "Teguran Cucu Nabi Muhammad Ke Muslim Yang Sebut Virus Corona Azab China." diakses 30 April 2020.https://www.suara.com/news/2020/02/11/123748/teguran -cucu-nabi-muhammad-ke-muslim-yang-sebut-virus-coro-naazab-china.

Giuffrida, Angela, and Sam Jones. "Italy to Unveil Lockdown Relief Package as Protests Continue.” diakses 30 April 2020. https://www.theguardian.com/world/2020/oct/27/italy-tounveil-lockdown-relief-package-as-protests-continue.

Kharomah, Alfiyah. "Cara Islam Selesaikan Pandemi Covid-19." diakses30April2020.https://www.galamedianews.com/?arsip=2 50218\&judul=cara-islam-selesaikan-pandemi-covid-19.

Mukaromah, Vina Fadhrotul. "Apa Itu Virus Corona, Yang Jadi Penyebab Penyakit Covid-19, MERS, Dan SARS?," diakses 18 Juni2021, https://www.kompas.com/tren/read/2020/03/ 17/15300 0465/apa-itu-virus-corona-yang-jadi-penyebabpenyakit-covid-19-mers-dan-sars?page $=$ all.

Scrivener, Glen. "Pandemics and Public Worship Throughout History." diakses 30 April 2020. https://www.thegospelcoa lition.org/article/4-lessons-church-history/.

Witvielt, John D. "Pandemics and Public Worship Throughout History." diakses 30 April 2020. https://worship.calvin.edu/ resources/resource-library/pandemics-and-public-worshipthroughout-history. 